Research Article

\title{
Effects of Liraglutide on Left Ventricular Function: A Meta-Analysis of Randomized, Placebo-Controlled Trials
}

\author{
Zhaoshuang Zhong $\mathbb{D}^{1}{ }^{1}$ Kaiming Chen $\mathbb{D}^{2},{ }^{2}$ Yan Zhao $\mathbb{D}^{1},{ }^{1}$ and Shuyue Xia $\mathbb{D}^{1}$ \\ ${ }^{1}$ Department of Respiratory, Central Hospital, Shenyang Medical College, Shenyang, China \\ ${ }^{2}$ Department of Cardiovascular Disease, Central Hospital, Shenyang Medical College, Shenyang, China
}

Correspondence should be addressed to Shuyue Xia; dr_syxia@qq.com

Received 17 March 2021; Accepted 3 June 2021; Published 15 June 2021

Academic Editor: Faustino R. Perez-Lopez

Copyright ( $) 2021$ Zhaoshuang Zhong et al. This is an open access article distributed under the Creative Commons Attribution License, which permits unrestricted use, distribution, and reproduction in any medium, provided the original work is properly cited.

\begin{abstract}
Background. The effects of liraglutide treatment on the left ventricular systolic and diastolic function remain unclear. Methods. This meta-analysis was conducted according to the preferred reporting items for systematic reviews and meta-analysis (PRISMA) statement. All relevant randomized, placebo-controlled trials (RCTs) were identified by searching PubMed, EMBASE, Cochrane Library, and ISI Web of Science from the establishment to January 2021 without language limitations. The weighted mean difference (WMD) with 95\% confidence intervals (CIs) was calculated. Results. Ten placebo-controlled RCTs involving a total of 732 cases were included in the meta-analysis. Compared with the placebo group, liraglutide therapy showed no beneficial effect on the left ventricular ejection fraction (LVEF) at the end of the study (WMD: $2.120,95 \% \mathrm{CI}:-0.688$ to $4.929, P=0.139$ ) and $\Delta \mathrm{LVEF}$ during the trial period (WMD: $-0.651,95 \% \mathrm{CI}:-1.649$ to $0.348, P=0.202$ ). Similarly, no statistical differences were noted in diastolic function parameters between the two groups, including the value early diastolic filling velocity $(E) /$ the mitral annular early diastolic velocity $\left(e^{\prime}\right.$ ) (WMD: $-0.763,95 \% \mathrm{CI}:-2.157$ to $0.630, P=0.283$ ), $\Delta e^{\prime}$ (WMD: $-0.069,95 \% \mathrm{CI}:-0.481$ to 0.343 , $P=0.742$ ), and $\Delta E / e^{\prime}$ (WMD: $-0.683,95 \% \mathrm{CI}:-1.663$ to $0.298, P=0.172$ ). Conclusions. Liraglutide treatment did not improve the left ventricular systolic and diastolic function. Given the study's limitations, further investigation may be warranted.
\end{abstract}

\section{Introduction}

Glucagon-like peptide-1 (GLP-1) is a gut-derived hormone that can stimulate glucose-dependent insulin secretion from pancreatic beta cells in response to intake $[1,2]$. Since GLP-1 is degraded rapidly by the enzyme dipeptidyl peptidase-4 (DPP4), GLP-1 receptor agonists with natural or modified structures resistant to the inactivation by DPP-4 were developed [3]. Among the GLP-1 receptor agonists, liraglutide was proved to be associated with a lower incidence of cardiovascular disease (CVD) events compared to placebo [4]. The potential mechanisms may involve improving postprandial lipid metabolism [5] and anti-inflammatory effects [6], leading to benefits on other cardiometabolic risk factors [7].

However, the effects of liraglutide on cardiac function remain unclear. In the Liraglutide Effect and Action in Diabetes: Evaluation of Cardiovascular Outcome Results
(LEADER) trial [8], liraglutide treatment failed to reach the statistical significance on the endpoint of hospitalization for heart failure. On the contrary, in a recent meta-analysis, GLP-1 receptor agonists did show beneficial effects on heart failure outcomes, though the explanation for the results was still pending [9]. Many other studies showed similar controversial results. To further clarify the effects of liraglutide on left ventricular function, we performed this meta-analysis with randomized, placebo-controlled trials (RCTs).

\section{Methods}

2.1. Search Strategy. This meta-analysis was conducted according to the preferred reporting items for systematic reviews and meta-analysis (PRISMA) statement [10]. All published RCTs comparing the effects of liraglutide and placebo on left ventricular function were identified by 
searching PubMed, EMBASE, Cochrane Library, and ISI Web of Science from the establishment to January 2021 without language restrictions. The search formula was performed as (liraglutide) AND (left ventricular) AND (randomized). Two authors went through the titles and abstracts of the records and identified eligible articles independently. Disagreements were resolved by discussion or referring to the third author (S.-Y.X.).

2.2. Inclusion and Exclusion Criteria. The inclusion criteria contained the following: (1) RCT, (2) liraglutide therapy was administered and compared with the placebo-controlled group, and (3) reported at least one of the following outcomes: for systolic function, the left ventricular ejection fraction (LVEF) at the end of the study or the changes of LVEF during the study ( $\triangle \mathrm{LVEF}$ ); for diastolic function, the mitral annular early diastolic velocity $\left(e^{\prime}\right)$, the value early diastolic filling velocity $(E) / e^{\prime}$, or the changes of the two indicators during the trial $\left(\Delta e^{\prime}\right.$ and $\left.\Delta E / e^{\prime}\right)$. Duplicated publications, reviews, meeting abstracts, and case reports were excluded.

2.3. Data Extraction and Quality Assessment. Two authors used a predesigned structured form to extract data from each study independently. The data elements included (1) study information, such as the first author's name, publication year, sample size, intervention strategies, and follow-up information; (2) patient characteristics, such as the mean age, the proportion of hypertension, diabetes, and smokers; (3) measurement of the baseline LVEF, $e^{\prime}$, and $E / e^{\prime}$; (4) outcomes as listed above. The methodological qualities of the included trials were assessed by two independent authors using the modified Jadad scale [11]. The disagreements were resolved by discussion or referring to the third author (S.Y.X.).

2.4. Statistical Analysis. We calculated the weighted mean difference (WMD) with 95\% confidence intervals (CIs) for continuous outcomes. The $I^{2}$ statistic was used to measure the heterogeneity across the included studies, and a randomeffect (RE) model was applied for all pooled outcomes regardless of heterogeneity [12]. In the case of significant heterogeneity, the sensitivity or subgroup analysis would be considered. The publication bias was evaluated by funnel plots with Begg's test [13]. Two-sided $P<0.05$ indicated a statistical significance. All analyses were completed using Stata v12.0 (Stata Corp, College Station, TX, USA) with the metan function.

\section{Results}

3.1. Basic Characteristics of Included Studies. A total of 136 records were initially identified by our search strategy, in which 56 duplicates were removed. After a title and abstract screening, another 60 citations were excluded as reviews, meeting abstracts, commentaries, case reports, or irrelevant studies. Among the 20 full-text review articles, ten were further excluded for reasons such as substudy [14], registering as one trial [15], comparing with other drugs, or no available data for pooling [16, 17]. Finally, ten placebocontrolled RCTs [18-27] involving a total of 732 cases were included in the meta-analysis. The detailed flowchart is shown in Figure 1. The baseline characteristics of the studies are presented in Tables 1 and 2 . The sensitivity analyses and publication assessments for each endpoint are listed in the Supplementary Materials (online suppl. Figures 1 and 2). No publication bias was found.

3.2. Methodological Quality Assessment. The methodological quality was assessed by the modified Jadad scale, composed of randomization, double blinding, withdrawals and dropouts, and allocation concealment [11]. The modified Jadad scores of the enrolled trials ranged from 5 to 7 , as presented in Table 3.

\subsection{Meta-Analysis Results}

3.3.1. Left Ventricular Systolic Function. Six studies [20, 22, 23, 25-27] involving 342 cases reported the LVEF at the end of the study. Compared to the placebo group, liraglutide therapy showed no benefits on LVEF $\left(I^{2}=70.7 \%\right.$; WMD: 2.120 , 95\% CI: -0.688 to $4.929, P=0.139$ ) (Figure 2). The outcome of $\triangle \mathrm{LVEF}$ was reported by four RCTs $[19,21,24,26]$, including 397 cases. No difference was noted between the liraglutide and the placebo group as well $\left(I^{2}=0.0 \%\right.$; WMD: $-0.651,95 \% \mathrm{CI}:-1.649$ to 0.348 , $P=0.202$ ) (Figure 3).

3.3.2. Left Ventricular Diastolic Function. Since only one study [18] reported the endpoint of $e^{\prime}$, no data were available for the pooling analysis. Three RCTs $[18,20,22]$ presented $E / e^{\prime}$ at the end of the study, and the results were comparable between the liraglutide and the placebo group $\left(I^{2}=0.0 \%\right.$; WMD: $-0.763,95 \% \mathrm{CI}:-2.157$ to $0.630, P=0.283)$. Four studies $[18,19,21,24]$ reported the outcomes of $\Delta e^{\prime}$ and $\Delta E / e^{\prime}$. Similarly, no statistical differences were noted between the two groups, neither $\Delta e^{\prime} \quad\left(I^{2}=52.8 \%\right.$; WMD: $-0.069,95 \% \mathrm{CI}:-0.481$ to $0.343, P=0.742$ ) (Figure 4 ) nor $\Delta E / e^{\prime}\left(I^{2}=53.2 \%\right.$; WMD: $-0.683,95 \% \mathrm{CI}:-1.663$ to 0.298 , $P=0.172$ ) (Figure 5).

\section{Discussion}

In this meta-analysis of placebo-controlled RCTs, we examined the effect of liraglutide treatment on left ventricular function, with or without diabetes, heart failure, and coronary artery disease. The parameters of LVEF, $e^{\prime}$, and E/ $e^{\prime}$ were measured by echocardiography, magnetic resonance, or the pulse indicator continuous cardiac output (PICCO) system. The results showed that liraglutide did not affect the left ventricular systolic or diastolic function.

GLP-1 receptor agonists demonstrated beneficial effects on CVD events and mortality in several studies [28]. The potential mechanisms may involve improving postprandial lipid metabolism [5], endothelial function and anti- 


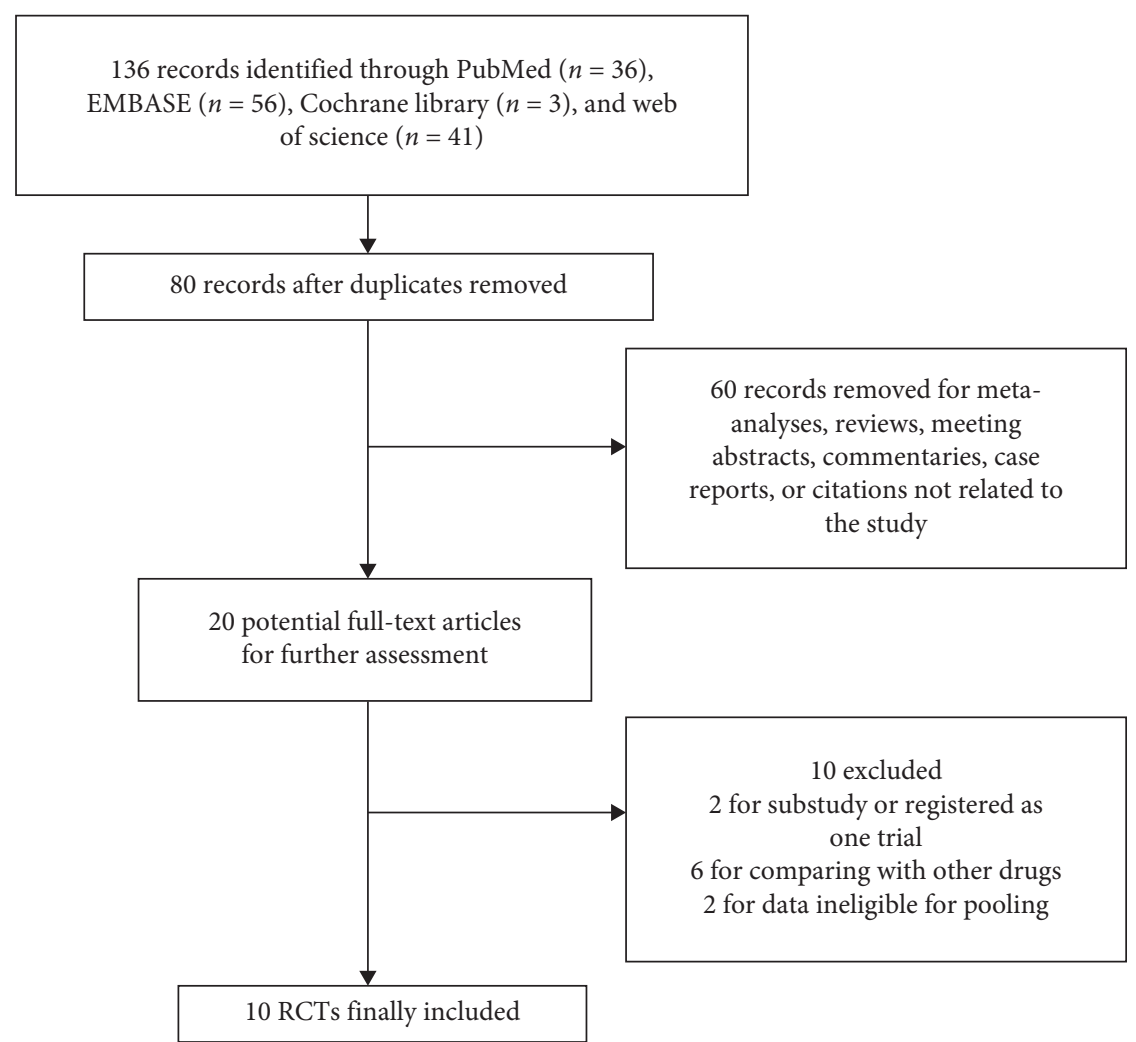

FIgURE 1: Flowchart of study selection.

TABLE 1: Characteristics of included studies.

\begin{tabular}{|c|c|c|c|c|c|c|c|c|c|}
\hline Study & Year & LG/CG & $\begin{array}{l}\text { Sample } \\
\text { size, } n\end{array}$ & Age, $y$ & $\begin{array}{c}\text { Males, } \\
n(\%)\end{array}$ & $\begin{array}{c}\text { Hypertension, } \\
n(\%) \\
\end{array}$ & $\begin{array}{c}\text { Diabetes, } \\
n(\%) \\
\end{array}$ & $\begin{array}{c}\text { Smokers, } \\
n(\%) \\
\end{array}$ & $\begin{array}{c}\text { Follow- } \\
\text { up }\end{array}$ \\
\hline $\begin{array}{l}\text { Kumarathurai } \\
\text { et al. [18] }\end{array}$ & 2021 & $\begin{array}{l}\text { LG } \\
\text { CG }\end{array}$ & $\begin{array}{l}30 \\
30\end{array}$ & $63.1 \pm 6.6$ & $24(80)$ & $23(77)$ & $30(100)$ & $14(36)$ & 12 weeks \\
\hline Paiman et al. [19] & 2020 & $\begin{array}{l}\text { LG } \\
\text { CG }\end{array}$ & $\begin{array}{l}22 \\
25 \\
\end{array}$ & $\begin{array}{c}55 \pm 11 \\
55 \pm 9\end{array}$ & $\begin{array}{c}8(36) \\
11(44) \\
\end{array}$ & NR & $\begin{array}{l}22(100) \\
25(100)\end{array}$ & $\begin{array}{l}8(36) \\
5(20) \\
\end{array}$ & 26 weeks \\
\hline Wagner et al. [20] & 2019 & $\begin{array}{l}\text { LG } \\
\text { CG }\end{array}$ & $\begin{array}{l}12 \\
12\end{array}$ & $\begin{array}{c}53.2 \pm 9.7 \\
52.6 \pm 13.8\end{array}$ & $\begin{array}{l}4(33) \\
5(42)\end{array}$ & $\begin{array}{l}7(58) \\
8(67)\end{array}$ & $\begin{array}{l}12(100) \\
12(100)\end{array}$ & $\begin{array}{l}2(17) \\
3(25)\end{array}$ & $\begin{array}{c}6 \\
\text { months }\end{array}$ \\
\hline Bizino et al. [21] & 2019 & $\begin{array}{l}\text { LG } \\
\text { CG }\end{array}$ & $\begin{array}{l}23 \\
26 \\
\end{array}$ & $\begin{array}{l}60 \pm 6 \\
59 \pm 7 \\
\end{array}$ & $\begin{array}{l}14(61) \\
15(58)\end{array}$ & NR & $\begin{array}{l}23(100) \\
26(100)\end{array}$ & $\begin{array}{l}13(56) \\
18(69)\end{array}$ & 26 weeks \\
\hline Jorgensen et al. [22] & 2017 & $\begin{array}{l}\text { LG } \\
\text { CG }\end{array}$ & $\begin{array}{l}16 \\
16\end{array}$ & $57 \pm 10$ & NR & NR & $\begin{array}{l}16(100) \\
16(100)\end{array}$ & NR & 16 weeks \\
\hline Zhang et al. [23] & 2017 & $\begin{array}{l}\text { LG } \\
\text { CG }\end{array}$ & $\begin{array}{l}26 \\
26 \\
\end{array}$ & $\begin{array}{l}59.1 \pm 11.8 \\
58.7 \pm 11.4 \\
\end{array}$ & $\begin{array}{l}20(77) \\
19(73) \\
\end{array}$ & $\begin{array}{l}17(65) \\
16(62) \\
\end{array}$ & $\begin{array}{l}5(19) \\
7(27) \\
\end{array}$ & $\begin{array}{l}15(58) \\
17(65) \\
\end{array}$ & 1 week \\
\hline Jorsal et al. [24] & 2017 & $\begin{array}{l}\text { LG } \\
\text { CG }\end{array}$ & $\begin{array}{l}122 \\
119 \\
\end{array}$ & $\begin{array}{c}65 \pm 9.2 \\
65 \pm 10.7 \\
\end{array}$ & $\begin{array}{l}109(89) \\
106(89) \\
\end{array}$ & NR & $\begin{array}{l}39(32) \\
35(29) \\
\end{array}$ & $\begin{array}{l}25(21) \\
23(19) \\
\end{array}$ & 24 weeks \\
\hline Chen et al. [25] & 2016 & $\begin{array}{l}\text { LG } \\
\text { CG }\end{array}$ & $\begin{array}{l}45 \\
45\end{array}$ & $\begin{array}{l}58.0 \pm 11.7 \\
59.0 \pm 12.1\end{array}$ & $\begin{array}{l}34(76) \\
32(71)\end{array}$ & $\begin{array}{l}27(60) \\
29(64)\end{array}$ & $\begin{array}{c}9(20) \\
13(28)\end{array}$ & $\begin{array}{l}25(56) \\
27(60)\end{array}$ & $\begin{array}{c}3 \\
\text { months }\end{array}$ \\
\hline $\begin{array}{l}\text { Kumarathurai et al. } \\
{[26]}\end{array}$ & 2016 & $\begin{array}{l}\text { LG } \\
\text { CG }\end{array}$ & $\begin{array}{l}30 \\
30 \\
\end{array}$ & $61.8 \pm 7.6$ & $31(79)$ & $29(74)$ & $30(100)$ & $14(36)$ & 12 weeks \\
\hline Chen et al. [27] & 2016 & $\begin{array}{l}\text { LG } \\
\text { CG }\end{array}$ & $\begin{array}{l}39 \\
38\end{array}$ & $\begin{array}{l}57.1 \pm 13.0 \\
58.7 \pm 12.7\end{array}$ & $\begin{array}{l}27(69) \\
26(68)\end{array}$ & $\begin{array}{l}18(46) \\
19(48)\end{array}$ & $\begin{array}{l}5(13) \\
7(18)\end{array}$ & $\begin{array}{l}13(33) \\
14(37)\end{array}$ & $\begin{array}{c}3 \\
\text { months }\end{array}$ \\
\hline
\end{tabular}

LG: liraglutide group; CG: control group; NR: not reported. 
TABLE 2: Characteristics of included studies.

\begin{tabular}{|c|c|c|c|c|c|c|c|}
\hline Study & Year & Liraglutide intervention & $\begin{array}{l}\text { LG/ } \\
\text { CG }\end{array}$ & $\begin{array}{l}\mathrm{LVEF} \\
(\%)\end{array}$ & $\begin{array}{l}e^{\prime}(\mathrm{cm} / \\
\mathrm{s})\end{array}$ & $E / e^{\prime}$ & $\begin{array}{l}\text { Heart rate } \\
(\mathrm{bpm})\end{array}$ \\
\hline $\begin{array}{l}\text { Kumarathurai et al. } \\
{[18]}\end{array}$ & 2021 & $\begin{array}{l}0.6 \mathrm{mg} / \text { day, increased every } 14 \text { days up to } 1.8 \mathrm{mg} / \\
\text { day }\end{array}$ & $\begin{array}{l}\text { LG } \\
\text { CG }\end{array}$ & $58.9 \pm 7.2$ & $5.7 \pm 1.6$ & $15.36 \pm 6.4$ & $68.6 \pm 10.1$ \\
\hline Paiman et al. [19] & 2020 & $0.6 \mathrm{mg} /$ day, increased every 7 days up to $1.8 \mathrm{mg} /$ day & $\begin{array}{l}\text { LG } \\
\text { CG }\end{array}$ & $\begin{array}{l}56 \pm 8 \\
57 \pm 7\end{array}$ & $\begin{array}{l}5.3 \pm 2.1 \\
5.7 \pm 1.9\end{array}$ & $\begin{array}{l}7.4 \pm 3.9 \\
7.4 \pm 3.3\end{array}$ & $\begin{array}{l}73 \pm 13 \\
77 \pm 11\end{array}$ \\
\hline Wagner et al. [20] & 2019 & $0.6 \mathrm{mg} /$ day, increased every 7 days up to $1.8 \mathrm{mg} /$ day & $\begin{array}{l}\text { LG } \\
\text { CG }\end{array}$ & $\begin{array}{l}62 \pm 7 \\
64 \pm 5\end{array}$ & NR & $\begin{array}{l}8.8 \pm 2.3 \\
9.7 \pm 2.6\end{array}$ & NR \\
\hline Bizino et al. [21] & 2019 & $0.6 \mathrm{mg} /$ day, increased every 7 days up to $1.8 \mathrm{mg} /$ day & $\begin{array}{l}\text { LG } \\
\text { CG }\end{array}$ & $\begin{array}{l}55 \pm 5.8 \\
55 \pm 4.5\end{array}$ & $\begin{array}{l}6.0 \pm 1.6 \\
6.0 \pm 1.8\end{array}$ & $\begin{array}{l}7.3 \pm 2.9 \\
7.9 \pm 2.3\end{array}$ & $\begin{array}{c}70 \pm 9 \\
70 \pm 12\end{array}$ \\
\hline $\begin{array}{l}\text { Jorgensen et al. } \\
\text { [22] }\end{array}$ & 2017 & $0.6 \mathrm{mg} /$ day, increased every 7 days up to $1.8 \mathrm{mg} /$ day & $\begin{array}{l}\text { LG } \\
\text { CG }\end{array}$ & $\begin{array}{l}59.2 \pm 6.1 \\
60.7 \pm 6.6\end{array}$ & NR & $\begin{array}{l}8.1 \pm 1.9 \\
8.2 \pm 2.3\end{array}$ & $\begin{array}{l}80.4 \pm 8.5 \\
81.3 \pm 8.3\end{array}$ \\
\hline Zhang et al. [23] & 2017 & $\begin{array}{l}0.6 \mathrm{mg} / \text { day for } 2 \text { days, } 1.2 \mathrm{mg} / \text { day for } 2 \text { days, } 1.8 \mathrm{mg} / \\
\text { day for } 3 \text { days }\end{array}$ & $\begin{array}{l}\text { LG } \\
\text { CG }\end{array}$ & $\begin{array}{l}42.2 \pm 7.1 \\
42.1 \pm 7.3\end{array}$ & NR & NR & $\begin{array}{l}67 \pm 10 \\
67 \pm 11 \\
\end{array}$ \\
\hline Jorsal et al. [24] & 2017 & $0.6 \mathrm{mg} /$ day, increased every 7 days up to $1.8 \mathrm{mg} /$ day & $\begin{array}{l}\text { LG } \\
\text { CG }\end{array}$ & $\begin{array}{l}33.7 \pm 7.6 \\
35.4 \pm 9.4\end{array}$ & $\begin{array}{l}6.6 \pm 2.1 \\
6.9 \pm 2.4\end{array}$ & $\begin{array}{l}12.6 \pm 6.0 \\
11.7 \pm 5.5\end{array}$ & $\begin{array}{c}76.3 \pm 15.1 \\
75.1 \pm 9.6\end{array}$ \\
\hline Chen et al. [25] & 2016 & $\begin{array}{l}0.6 \mathrm{mg} / \text { day for } 2 \text { days, } 1.2 \mathrm{mg} / \text { day for } 2 \text { days, } 1.8 \mathrm{mg} / \\
\text { day for } 3 \text { days }\end{array}$ & $\begin{array}{l}\text { LG } \\
\text { CG }\end{array}$ & $\begin{array}{l}47.2 \pm 5.1 \\
47.7 \pm 5.1\end{array}$ & NR & NR & $71.7 \pm 12.1$ \\
\hline $\begin{array}{l}\text { Kumarathurai et al. } \\
\text { [26] }\end{array}$ & 2016 & $\begin{array}{l}0.6 \mathrm{mg} / \text { day, increased every } 14 \text { days up to } 1.8 \mathrm{mg} / \\
\text { day }\end{array}$ & $\begin{array}{l}\text { LG } \\
\text { CG }\end{array}$ & $58.9 \pm 7.6$ & NR & NR & NR \\
\hline Chen et al. [27] & 2016 & $\begin{array}{c}1.8 \mathrm{mg} \text { before intervention, } 0.6 \mathrm{mg} / \text { day for } 2 \text { days, } \\
1.2 \mathrm{mg} / \text { day for } 2 \text { days, } 1.8 \mathrm{mg} / \text { day for } 3 \text { days }\end{array}$ & $\begin{array}{l}\text { LG } \\
\text { CG }\end{array}$ & $\begin{array}{l}51.3 \pm 8.1 \\
50.7 \pm 7.6\end{array}$ & NR & NR & NR \\
\hline
\end{tabular}

LG: liraglutide group; CG: control group; NR: not reported; LVEF: left ventricular ejection fraction; $E$ : the value early diastolic filling velocity; $e^{\prime}$ : the mitral annular early diastolic velocity.

TABle 3: Assessment of the methodological quality of included studies [11].

\begin{tabular}{|c|c|c|c|c|c|}
\hline Author & Randomization & Double blinding & Allocation concealment & Withdrawals/dropouts & Scores \\
\hline Kumarathurai et al. [18] & Yes & Yes & Unclear & Yes & 6 \\
\hline Paiman et al. [19] & Yes & Yes & Yes & Yes & 7 \\
\hline Wagner et al. [20] & Yes & Yes & Unclear & Yes & 6 \\
\hline Bizino et al. [21] & Yes & Yes & Yes & Yes & 7 \\
\hline Jorgensen et al. [22] & Yes (method unclear) & Yes & Unclear & Yes & 5 \\
\hline Zhang et al. [23] & Yes & Yes & Unclear & Yes & 6 \\
\hline Jorsal et al. [24] & Yes & Yes & Yes & Yes & 7 \\
\hline Chen et al. [25] & Yes & Yes & Unclear & Yes & 6 \\
\hline Kumarathurai et al. [26] & Yes & Yes & Unclear & Yes & 6 \\
\hline Chen et al. [27] & Yes & Yes & Unclear & Yes & 6 \\
\hline
\end{tabular}

inflammatory effects $[29,30]$, and other benefits directly on the coronary blood flow and myocardial energy metabolism [31-33]. However, the effects of GLP-1 receptor agonists on left ventricular function remain to be established. In previous studies, GLP-1 was associated with improved left ventricular systolic function [34-36]. As a primary GLP-1 receptor agonist, liraglutide showed beneficial effects on LVEF as well, even in patients without diabetes [25, 37]. Nevertheless, most of the studies' population was relatively small or not placebo-matched. In the LEADER trial, liraglutide showed no effect on hospitalization for heart failure, and many other studies showed similar controversial results [8].

To clarify this issue, we conducted the present study, and the results showed that liraglutide had no positive effects on LVEF. In our study, the outcome of LVEF at the end of the study showed significant heterogeneity $\left(I^{2}=70.7 \%\right)$. We performed the sensitivity analysis, and the results are listed in the Supplementary Materials (online suppl. Figure 1). Due to the limited number of enrolled studies, the subgroup analysis was not carried out. Given the influence on statistical power, we would prefer to regard LVEF at the end of the study as an ancillary finding to $\triangle \mathrm{LVEF}$. Furthermore, though not included in the meta-analysis due to the data format, the Functional Impact of GLP-1 for Heart Failure Treatment (FIGHT) trial also showed comparable results between liraglutide and placebo on left ventricular systolic function [16]. Consequently, as hypothesized by some scholars, the beneficial effect of GLP-1 receptor agonists on hospital admission for heart failure may attribute to the reduction in myocardial infarction rather than immediate improvement in systolic function [9].

The effects of liraglutide on left ventricular diastolic function were also investigated. Lambadiari et al. reported 


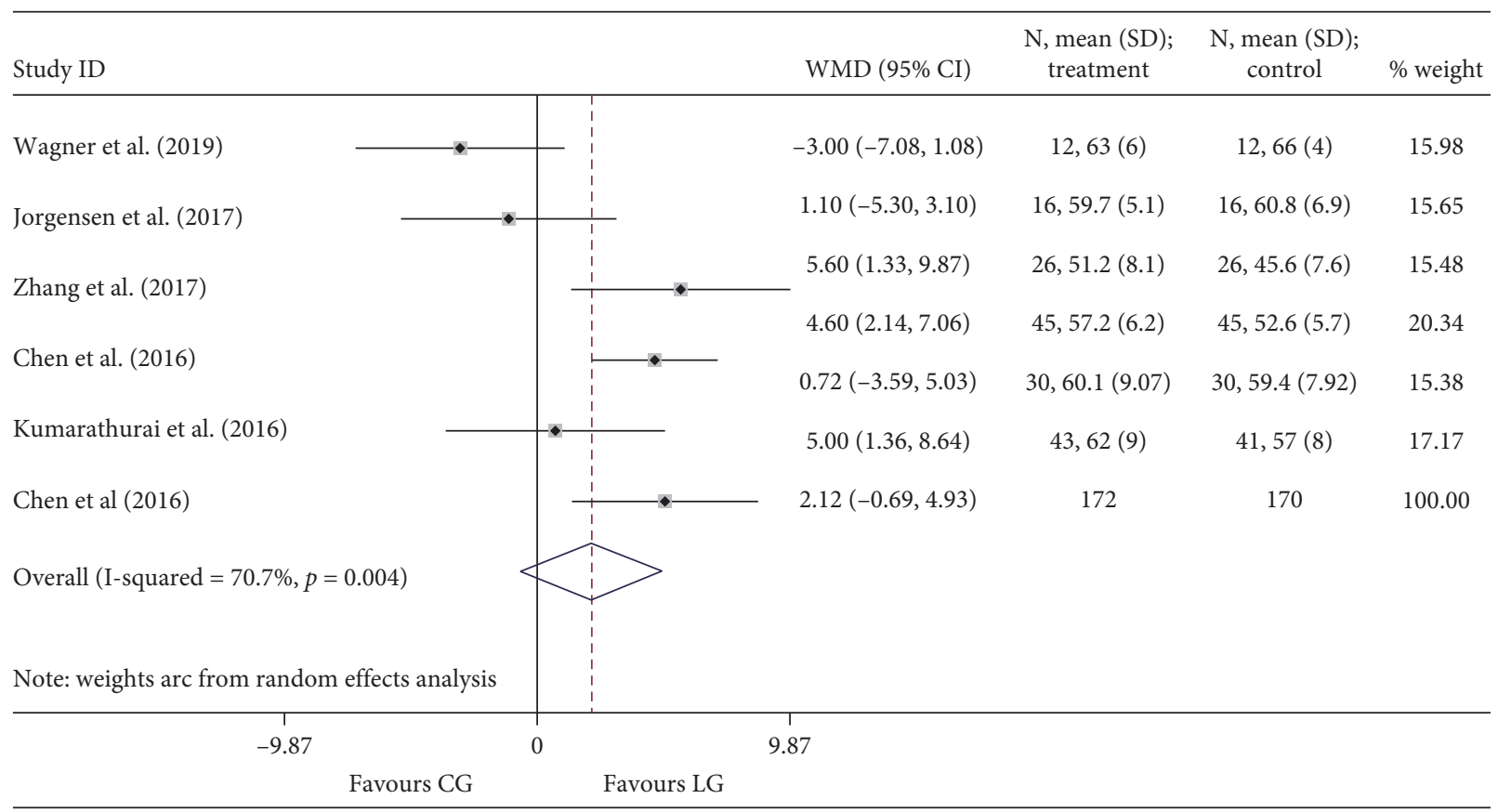

FIGURE 2: Forest plot for LVEF. LVEF: left ventricular ejection fraction; WMD: weighted mean difference; LG: liraglutide group; CG: control group.

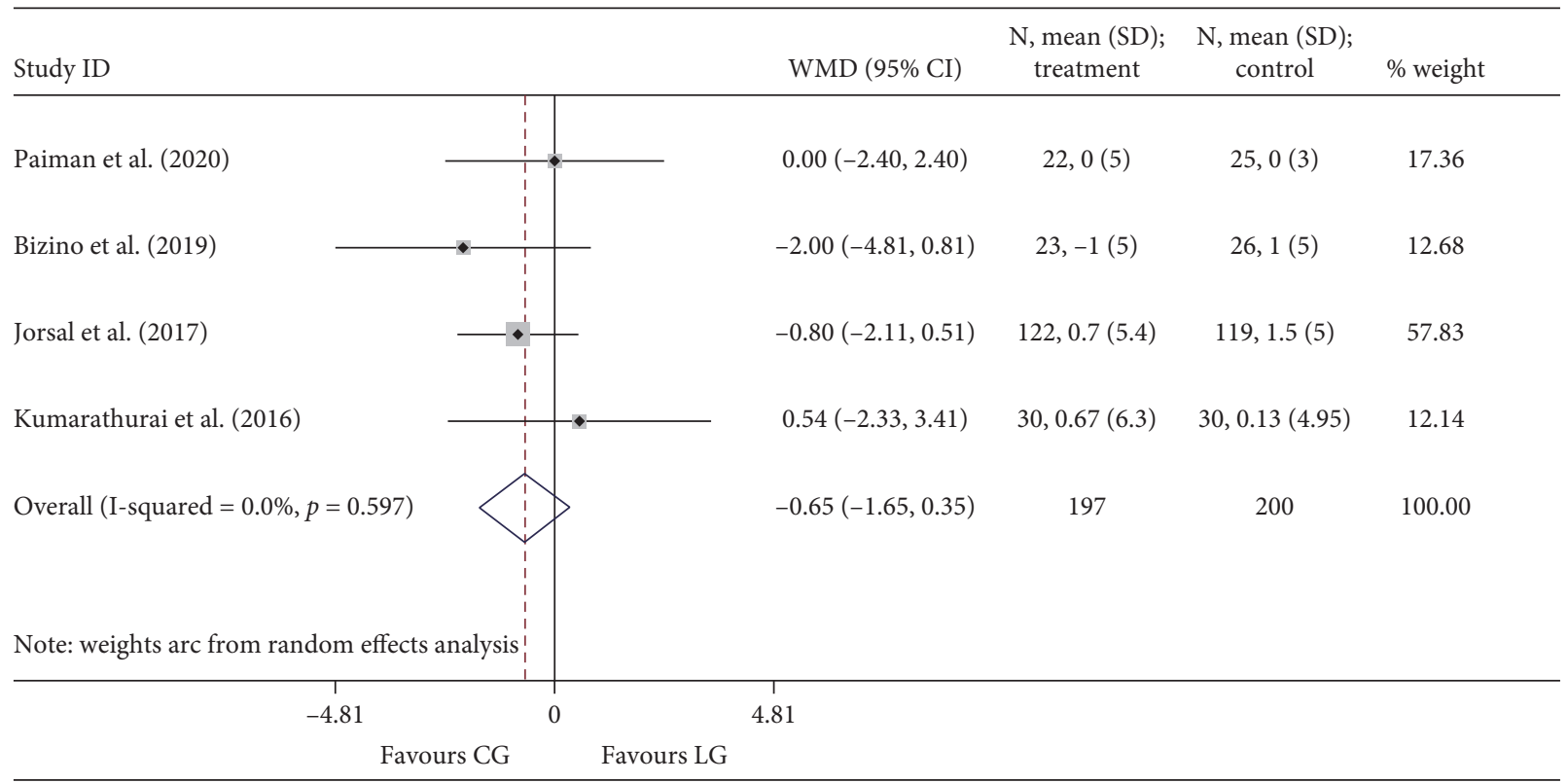

FIGURE 3: Forest plot for $\triangle$ LVEF. LVEF: left ventricular ejection fraction; WMD: weighted mean difference; LG: liraglutide group; CG: control group.

that a six-month treatment with liraglutide improves arterial stiffness and myocardial relaxation [38]. Bizino et al. found a 6-month treatment with liraglutide reduced early left ventricular diastolic filling and filling pressure [21]. On the contrary, Nyström et al. reported that, after an 18-week treatment of liraglutide, no improvement of diastolic function was observed compared with glimepiride [39]. In the study conducted by Jorgensen et al., liraglutide may weaken the beneficial effects of exercise on left ventricular diastolic function [22]. The present meta-analysis further confirmed that liraglutide had no benefits on left ventricular diastolic function. The potential explanations may be multiple. Several studies reported that GLP-1 receptor agonists, including liraglutide, were associated with a significant increase in heart rate [40, 41], which means adverse effects on left ventricular function [42] and cardiovascular mortality [43]. The mechanisms may involve sympathetic activity stimulation [44] and immediate effect 


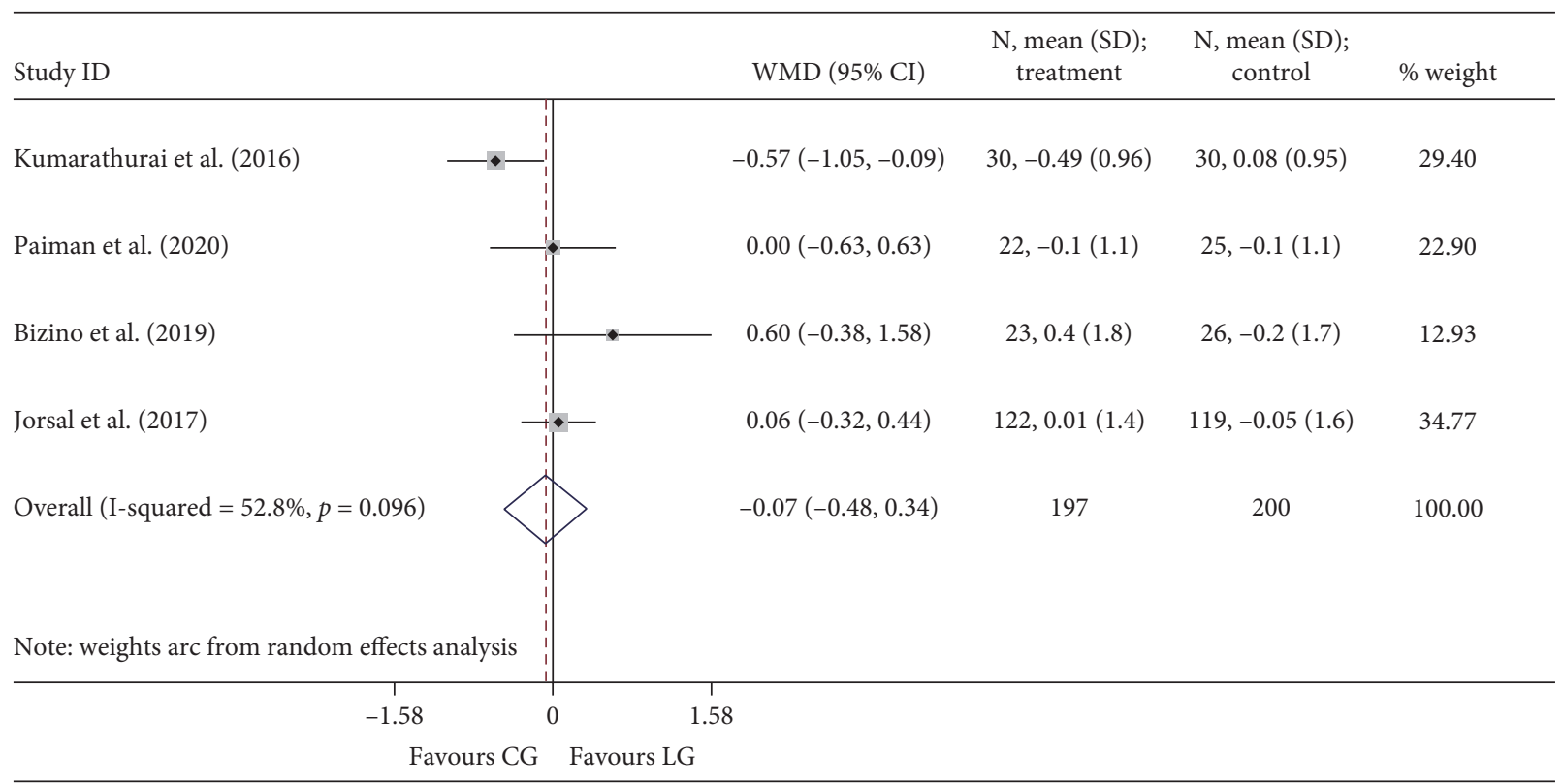

FIGURE 4: Forest plot for $\Delta e^{\prime} . E^{\prime}$ : the mitral annular early diastolic velocity; WMD: weighted mean difference; LG: liraglutide group; CG: control group.

\begin{tabular}{|c|c|c|c|c|}
\hline Study ID & WMD $(95 \%$ CI $)$ & $\begin{array}{l}\mathrm{N} \text {, mean }(\mathrm{SD}) ; \\
\text { treatment }\end{array}$ & $\begin{array}{c}\mathrm{N}, \text { mean }(\mathrm{SD}) ; \\
\text { control }\end{array}$ & $\%$ weight \\
\hline Kumarathurai et al. (2016) & $0.65(-0.92,-2.22)$ & $29,-0.2(2.61)$ & $29,-0.85(3.44)$ & 21.33 \\
\hline Paiman et al. (2020) & $-0.10(-1.53,1.33)$ & $22,-0.4(2.4)$ & $25,-0.1(2.6)$ & 23.55 \\
\hline Bizino et al. (2019) & $-1.50(-2.79,-1.21)$ & $23,-0.9(2.6)$ & $26,0.6(1.9)$ & 25.99 \\
\hline Jorsal et al. (2017) & $-1.40(-2.52,-0.28)$ & $122,-0.7(4.6)$ & $119,0.7(4.3)$ & 29.13 \\
\hline Overall $(\mathrm{I}$-squared $=52.8 \%, p=0.096)$ & $-0.68(-1.66,0.30)$ & 196 & 199 & 100.00 \\
\hline \multicolumn{5}{|l|}{ Note: weights arc from random effects analysis } \\
\hline-2.79 & 2.79 & & & \\
\hline Favou & & & & \\
\hline
\end{tabular}

FIGURE 5: Forest plot for $\Delta E / e^{\prime} . E$ : the value early diastolic filling velocity; $e^{\prime}$ : the mitral annular early diastolic velocity; WMD: weighted mean difference; LG: liraglutide group; CG: control group.

on GLP-1 receptors in the sinoatrial node [45]. It was hypothesized that beta blocker or other heart rate-lowering drugs might blunt this potential adverse effect [18]. However, in the LIVE study, an increase in heart rate was still observed in patients treating with maximum tolerable beta-blocker dose [24].

As far as we know, the present study is the first metaanalysis assessing the effect of liraglutide treatment on left ventricular systolic and diastolic function parameters using placebo-controlled RCTs. However, the potential limitations of the study should not be ignored. Due to the limited study number and population size, the power of the funnel plot asymmetry test for publication bias might be restricted, and we did not perform the subgroup analyses based on patients with or without diabetes, heart failure, and coronary disease, which might be responsible for the inconsistent findings across the enrolled studies. Furthermore, though highquality RCTs were enrolled, few data were available for pooling analysis, such as cardiac index, global longitudinal strain, and $E / A$ ratio. Despite this, LVEF, $e^{\prime}$, and $E / e^{\prime}$ were the most representative indicators for left ventricular function assessment, and the change in $E / e^{\prime}$ was associated 
with the NT-proBNP level [14]. Finally, the meta-analysis contained studies with different follow-up periods, intervention regimens, and patient's clinical features, which may also affect the analysis power. Therefore, the study results should be interpreted with caution and may warrant further investigation.

\section{Conclusion}

The present study demonstrated that liraglutide treatment did not improve left ventricular function, irrespective of systolic or diastolic parameters. Given the study's limitations, the results should be interpreted cautiously, and further investigation may be needed.

\section{Data Availability}

All the data that support the findings of this study are included within the article.

\section{Conflicts of Interest}

The authors declare that there are no conflicts of interest.

\section{Authors' Contributions}

Z.-S.Z. and S.-Y.X. conceived and designed the study. Z.S.Z., K.-M.C., and S.-Y.X. performed the study and wrote the main manuscript text. K.-M.C. and Y.Z. contributed to analysis tools and prepared figures. All authors reviewed the manuscript.

\section{Supplementary Materials}

Online suppl. Figure 1: sensitivity analysis for the endpoint of A, LVEF; B, $\Delta$ LVEF; C, $E / e^{\prime} ; \mathrm{D}, \Delta e^{\prime} ; \mathrm{E}, \Delta E / e^{\prime}$. Online suppl. Figure 2: funnel plot for the endpoint of A, LVEF; B, $\Delta \mathrm{LVEF} ; \mathrm{C}, E / e^{\prime} ; \mathrm{D}, \Delta e^{\prime} ; \mathrm{E}, \Delta E / e^{\prime}$. (Supplementary Materials)

\section{References}

[1] D. J. Drucker and M. A. Nauck, "The incretin system: glucagon-like peptide-1 receptor agonists and dipeptidyl peptidase- 4 inhibitors in type 2 diabetes," The Lancet, vol. 368, no. 9548, pp. 1696-1705, 2006.

[2] D. J. Drucker, "The biology of incretin hormones," Cell Metabolism, vol. 3, no. 3, pp. 153-165, 2006.

[3] A. C. Sposito, O. Berwanger, L. S. F. de Carvalho, and J. F. K. Saraiva, "GLP-1RAs in type 2 diabetes: mechanisms that underlie cardiovascular effects and overview of cardiovascular outcome data," Cardiovascular Diabetology, vol. 17, no. 1, p. 157, 2018.

[4] B. Ahrén, L. Masmiquel, H. Kumar et al., "Efficacy and safety of once-weekly semaglutide versus once-daily sitagliptin as an add-on to metformin, thiazolidinediones, or both, in patients with type 2 diabetes (SUSTAIN 2): a 56-week, double-blind, phase 3a, randomised trial," The Lancet Diabetes \& Endocrinology, vol. 5, no. 5, pp. 341-354, 2017.

[5] B. Vergès, L. Duvillard, J. P. Pais de Barros et al., "Liraglutide reduces postprandial hyperlipidemia by increasing ApoB48 (apolipoprotein B48) catabolism and by reducing ApoB48 production in patients with type 2 diabetes mellitus,"
Arteriosclerosis, Thrombosis, and Vascular Biology, vol. 38, no. 9, pp. 2198-2206, 2018.

[6] B. J. von Scholten, F. Persson, S. Rosenlund et al., "Effects of liraglutide on cardiovascular risk biomarkers in patients with type 2 diabetes and albuminuria: a sub-analysis of a randomized, placebo-controlled, double-blind, crossover trial," Diabetes, Obesity and Metabolism, vol. 19, no. 6, pp. 901-905, 2017.

[7] N. Matikainen, S. Söderlund, E. Björnson et al., "Liraglutide treatment improves postprandial lipid metabolism and cardiometabolic risk factors in humans with adequately controlled type 2 diabetes: a single-centre randomized controlled study," Diabetes, Obesity and Metabolism, vol. 21, no. 1, pp. 84-94, 2019.

[8] S. P. Marso, G. H. Daniels, K. Brown-Frandsen et al., "Liraglutide and cardiovascular outcomes in type 2 diabetes," New England Journal of Medicine, vol. 375, no. 4, pp. 311-322, 2016.

[9] S. L. Kristensen, R. Rørth, P. S. Jhund et al., "Cardiovascular, mortality, and kidney outcomes with GLP-1 receptor agonists in patients with type 2 diabetes: a systematic review and metaanalysis of cardiovascular outcome trials," The Lancet Diabetes \& Endocrinology, vol. 7, no. 10, pp. 776-785, 2019.

[10] D. Moher, A. Liberati, J. Tetzlaff, D. G. Altman, and P. Group, "Preferred reporting items for systematic reviews and metaanalyses: the PRISMA statement," Annals of Internal Medicine, vol. 151, no. 4, pp. 264-269, 2009.

[11] M. Oremus, C. Wolfson, A. Perrault, L. Demers, F. Momoli, and Y. Moride, "Interrater reliability of the modified Jadad quality scale for systematic reviews of alzheimer's disease drug trials," Dementia and Geriatric Cognitive Disorders, vol. 12, no. 3, pp. 232-236, 2001.

[12] M. Cumpston, T. Li, M. J Page et al., "Updated guidance for trusted systematic reviews: a new edition of the cochrane handbook for systematic reviews of interventions," The Cochrane Database of Systematic Reviews, vol. 10, Article ID ED000142, 2019.

[13] C. B. Begg and M. Mazumdar, "Operating characteristics of a rank correlation test for publication bias," Biometrics, vol. 50, no. 4, pp. 1088-1101, 1994.

[14] R. Nielsen, A. Jorsal, R. S. Tougaard et al., "The impact of the glucagon-like peptide-1 receptor agonist liraglutide on natriuretic peptides in heart failure patients with reduced ejection fraction with and without type 2 diabetes," Diabetes, Obesity and Metabolism, vol. 22, no. 11, pp. 2141-2150, 2020.

[15] W. R. Chen, S. Y. Hu, Y. D. Chen et al., "Effects of liraglutide on left ventricular function in patients with ST-segment elevation myocardial infarction undergoing primary percutaneous coronary intervention," American Heart Journal, vol. 170, no. 5, pp. 845-854, 2015.

[16] K. B. Margulies, A. F. Hernandez, M. M. Redfield et al., "Effects of liraglutide on clinical stability among patients with advanced heart failure and reduced ejection fraction," Journal of the American Medical Association, vol. 316, no. 5, pp. 500-508, 2016.

[17] A. H. Hulst, M. J. Visscher, T. G. V. Cherpanath et al., "Effects of liraglutide on myocardial function after cardiac surgery: a secondary analysis of the randomised controlled globe trial," Journal of Clinical Medicine, vol. 9, no. 3, 2020.

[18] P. Kumarathurai, A. Sajadieh, C. Anholm, O. P. Kristiansen, S. B. Haugaard, and O. W. Nielsen, "Effects of liraglutide on diastolic function parameters in patients with type 2 diabetes and coronary artery disease: a randomized crossover study," Cardiovascular Diabetology, vol. 20, no. 1, p. 12, 2021. 
[19] E. H. M. Paiman, H. J. Eyk, M. M. A. Aalst et al., "Effect of liraglutide on cardiovascular function and myocardial tissue characteristics in type 2 diabetes patients of south asian descent living in The Netherlands: a double-blind, randomized, placebo-controlled trial," Journal of Magnetic Resonance Imaging, vol. 51, no. 6, pp. 1679-1688, 2020.

[20] A. M. Wägner, G. Miranda-Calderín, M. A. Ugarte-Lopetegui et al., "Effect of liraglutide on physical performance in type 2 diabetes: results of a randomized, double-blind, controlled trial (LIPER2)," Diabetes \& Metabolism, vol. 45, no. 3, pp. 268-275, 2019.

[21] M. B. Bizino, I. M. Jazet, J. J. M. Westenberg et al., "Effect of liraglutide on cardiac function in patients with type 2 diabetes mellitus: randomized placebo-controlled trial," Cardiovascular Diabetology, vol. 18, no. 1, p. 55, 2019.

[22] P. G. Jorgensen, M. T. Jensen, P Mensberg et al., "Effect of exercise combined with glucagon-like peptide-1 receptor agonist treatment on cardiac function: a randomized doubleblind placebo-controlled clinical trial," Diabetes, Obesity and Metabolism, vol. 19, no. 7, pp. 1040-1044, 2017.

[23] J. Y. Zhang, X. Y. Wang, and X. Wang, "Effects of liraglutide on hemodynamic parameters in patients with heart failure," Oncotarget, vol. 8, no. 37, pp. 62693-62702, 2017.

[24] A. Jorsal, C. Kistorp, P. Holmager et al., "Effect of liraglutide, a glucagon-like peptide-1 analogue, on left ventricular function in stable chronic heart failure patients with and without diabetes ( LIVE )-a multicentre, double-blind, randomised, placebo-controlled trial," European Journal of Heart Failure, vol. 19, no. 1, pp. 69-77, 2017.

[25] W.-R. Chen, X.-Q. Shen, Y. Zhang et al., "Effects of liraglutide on left ventricular function in patients with non-ST-segment elevation myocardial infarction," Endocrine, vol. 52, no. 3, pp. 516-526, 2016.

[26] P. Kumarathurai, C. Anholm, O. W. Nielsen et al., "Effects of the glucagon-like peptide-1 receptor agonist liraglutide on systolic function in patients with coronary artery disease and type 2 diabetes: a randomized double-blind placebo-controlled crossover study," Cardiovascular Diabetology, vol. 15, no. 1, p. 105, 2016.

[27] W. R. Chen, Y. D. Chen, F Tian et al., "Effects of liraglutide on reperfusion injury in patients with ST-segment-elevation myocardial infarction," Circulation. Cardiovascular Imaging, vol. 9, no. 12, 2016.

[28] Z. Zhang, X. Chen, P. Lu et al., "Incretin-based agents in type 2 diabetic patients at cardiovascular risk: compare the effect of GLP-1 agonists and DPP-4 inhibitors on cardiovascular and pancreatic outcomes," Cardiovascular Diabetology, vol. 16, no. 1, p. 31, 2017.

[29] H. Kushima, Y. Mori, M. Koshibu et al., "The role of endothelial nitric oxide in the anti-restenotic effects of liraglutide in a mouse model of restenosis," Cardiovascular Diabetology, vol. 16, no. 1, p. 122, 2017.

[30] G. Rakipovski, B. Rolin, J. Nøhr et al., "The GLP-1 analogs liraglutide and semaglutide reduce atherosclerosis in ApoE-/ - and LDLr-/- mice by a mechanism that includes inflammatory pathways," JACC: Basic to Translational Science, vol. 3 , no. 6, pp. 844-857, 2018.

[31] T. Zhao, P. Parikh, S. Bhashyam et al., "Direct effects of glucagon-like peptide-1 on myocardial contractility and glucose uptake in normal and postischemic isolated rat hearts," Journal of Pharmacology and Experimental Therapeutics, vol. 317, no. 3, pp. 1106-1113, 2006.

[32] L. A. Nikolaidis, D. Elahi, T. Hentosz et al., "Recombinant glucagon-like peptide-1 increases myocardial glucose uptake and improves left ventricular performance in conscious dogs with pacing-induced dilated cardiomyopathy," Circulation, vol. 110, no. 8, pp. 955-961, 2004.

[33] M. H. Noyan-Ashraf, M. A. Momen, K. Ban et al., "GLP-1R agonist liraglutide activates cytoprotective pathways and improves outcomes after experimental myocardial infarction in mice," Diabetes, vol. 58, no. 4, pp. 975-983, 2009.

[34] I. Poornima, S. B. Brown, S. Bhashyam, P. Parikh, H. Bolukoglu, and R. P. Shannon, "Chronic glucagon-like peptide-1 infusion sustains left ventricular systolic function and prolongs survival in the spontaneously hypertensive, heart failure-prone rat," Circulation: Heart Failure, vol. 1, no. 3, pp. 153-160, 2008.

[35] L. A. Nikolaidis, S. Mankad, G. G. Sokos et al., "Effects of glucagon-like peptide- 1 in patients with acute myocardial infarction and left ventricular dysfunction after successful reperfusion," Circulation, vol. 109, no. 8, pp. 962-965, 2004.

[36] L. M. McCormick, P. M. Heck, L. S. Ring et al., "Glucagon-like peptide-1 protects against ischemic left ventricular dysfunction during hyperglycemia in patients with coronary artery disease and type 2 diabetes mellitus," Cardiovascular Diabetology, vol. 14, no. 1, p. 102, 2015.

[37] F. Arturi, E. Succurro, S. Miceli et al., "Liraglutide improves cardiac function in patients with type 2 diabetes and chronic heart failure," Endocrine, vol. 57, no. 3, pp. 464-473, 2017.

[38] V. Lambadiari, G. Pavlidis, F. Kousathana et al., "Effects of 6month treatment with the glucagon like peptide-1 analogue liraglutide on arterial stiffness, left ventricular myocardial deformation and oxidative stress in subjects with newly diagnosed type 2 diabetes," Cardiovascular Diabetology, vol. 17, no. 1, p. $8,2018$.

[39] T. Nyström, I. Santos-Pardo, F. Hedberg et al., "Effects on subclinical heart failure in type 2 diabetic subjects on liraglutide treatment vs. glimepiride both in combination with metformin: a randomized open parallel-group study," Frontiers in Endocrinology, vol. 8, p. 325, 2017.

[40] J. R. Ussher and D. J. Drucker, "Cardiovascular actions of incretin-based therapies," Circulation Research, vol. 114, no. 11, pp. 1788-1803, 2014.

[41] L. E. Robinson, T. A. Holt, K. Rees, H. S. Randeva, and J. P. O'Hare, "Effects of exenatide and liraglutide on heart rate, blood pressure and body weight: systematic review and metaanalysis," BMJ Open, vol. 3, no. 1, 2013.

[42] S. Esfandiari, F. Fuchs, R. V. Wainstein et al., "Heart ratedependent left ventricular diastolic function in patients with and without heart failure," Journal of Cardiac Failure, vol. 21, no. 1 , pp. $68-75,2015$.

[43] M. Böhm, K. Swedberg, M. Komajda et al., "Heart rate as a risk factor in chronic heart failure (SHIFT): the association between heart rate and outcomes in a randomised placebocontrolled trial," The Lancet, vol. 376, no. 9744, pp. 886-894, 2010.

[44] H. Yamamoto, C. E. Lee, J. N. Marcus et al., "Glucagon-like peptide-1 receptor stimulation increases blood pressure and heart rate and activates autonomic regulatory neurons," Journal of Clinical Investigation, vol. 110, no. 1, pp. 43-52, 2002.

[45] C. Pyke, R. S. Heller, R. K. Kirk et al., "GLP-1 receptor localization in monkey and human tissue: novel distribution revealed with extensively validated monoclonal antibody," Endocrinology, vol. 155, no. 4, pp. 1280-1290, 2014. 